Atmos. Chem. Phys. Discuss., 6, 3321-3335, 2006

www.atmos-chem-phys-discuss.net/6/3321/2006/

(c) Author(s) 2006. This work is licensed

under a Creative Commons License.

Cirrus clouds and aerosols sudy

H. Chtioui et al.

\title{
Remote sensing of cirrus clouds and aerosols by a sun photometer in Tunisia
}

\section{H. Chtioui ${ }^{1}$, F. B. Mansour ${ }^{1}$, S. Elouragini ${ }^{1}$, and P. H. Flamant ${ }^{2}$}

1Unité de recherche "Energétique et Environnement" (03/UR 13-06), Institut Supérieur des Sciences Appliquées et de Technologie de Sousse, Cité Taffala, 4003 Sousse Ibn Khaldoun, Tunisia

${ }^{2}$ Laboratoire de Météorologie Dynamique, Ecole Polytechnique, 91128 Palaiseau, France

Received: 12 April 2005 - Accepted: 23 May 2005 - Published: 21 April 2006

Correspondence to: S. Elouragini (salem.elouragini@issatso.rnu.tn)

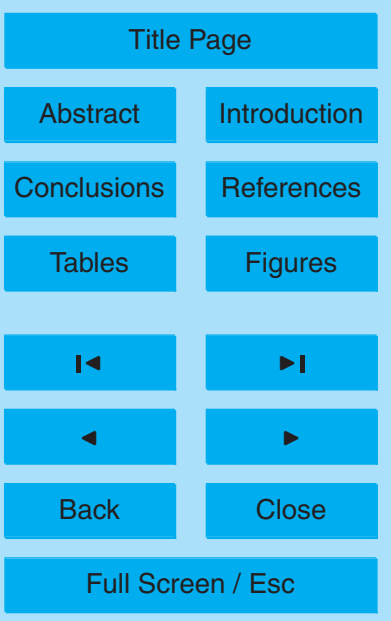

Printer-friendly Version

Interactive Discussion 


\section{Abstract}

Some ground based measurements of solar radiation by using a sun photometer, have been conducted in Tunisia during the period of November 2000-February 2002. Five key measurement sites were selected: Three Sites (Tunis, Sousse, Gabes) are located

5 on the Mediterranean coast and Two sites (Gafsa, Tozeur) on the boarder of Sahara. Over a total of 149 measurement days, 21 days are identified as clear sky, 114 days as Cirrus clouds and 14 days as aerosols.

Aerosols and Cirrus clouds Optical Thickness (AOT) are derived from photometric measurements at $532 \mathrm{~nm}$ wavelength. Spatial and temporal variabilities of AOT are presented and discussed in this paper.

Cirrus clouds were frequently observed at Gafsa and Tozeur where saharan aerosol events are expected to be more frequent than cirrus clouds. The mediterranean sea and saharan aerosols are suspected to have the main role in cirrus clouds formation, by providing water vapor and high concentrations of cloud condensation and ice forming 15 nuclei.

\section{Introduction}

Saharan dust can seriously affect the regional climate by changing interaction with solar radiation and by influencing the precipitation (Israelevich et al., 2003). They play a significant role in cirrus and contrails formation (Liou, 1986; Schumann, 2002; Sassen et al., 2003). The Mediterranean area is strongly affected by saharan aerosols coming from Norhern Africa (Dulac et al., 2003). The main sources and trajectories of the saharan dust storms over Northern Africa and the mediterranean were identified by Israelevich et al. (2002), Dayan et al. (1991).

Cirrus clouds cover permanently more than $20 \%$ of the Earth (Liou, 1986; Chepfer et al., 2001). They interact with aerosols and solar radiation and affect the earth's radiation budget (D'Almeida et al., 1987). The optical and microphysical properties of cirrus

Cirrus clouds and aerosols sudy

H. Chtioui et al.

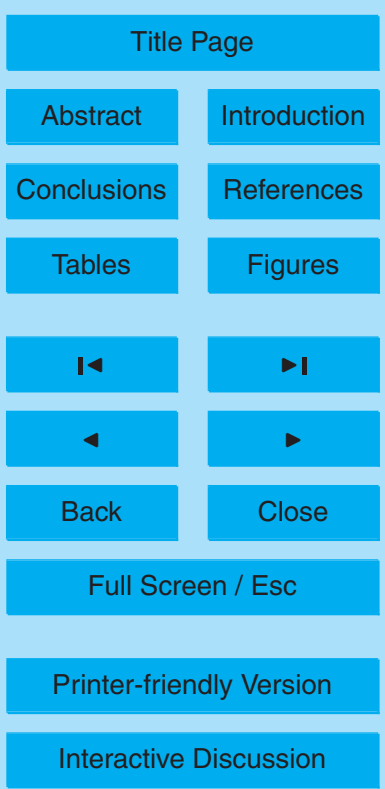


clouds and aerosols are important parameters for the earth radiation budget modelling (Chepfer et al., 1999). Their detailed and accurate characterization is an absolute need for the radiative transfer models which are used for atmospheric transmittance relevant to earth radiative budget and climate modelling.

5 In southern Europe and middle East, several experimental and numerical studies have been published on the impact of cirrus clouds and saharan aerosols on climate (Tanré et al., 1988; Deuze et al., 1988; Dulac et al., 1992; Müller et al., 2003).

Up to day, in Northern Africa, there is not sufficient ground stations and experimental equipment for appropriate atmospheric monitoring and ground based measurements 10 of solar radiation by sun photometer are limited either in space or in time. The whole amount of studies on saharan dust outbreaks over Northern Africa are based on satellite observations.

In Tunisia, we use a home made sun photometer to measure solar fluxes at $532 \mathrm{~nm}$ wavelength and derive aerosols and cirrus clouds optical thickness (AOT).

\section{Experiment design}

As mentioned above, North African regions and especially Tunisia and Libya are not yet covered by routinely operated ground based measurements of solar radiation such as the Aerosol Robotic Network (AERONET, Holben et al., 1998). It is only in the frame of EMAGPOT project (Etude à Mésoéchelle des Aérosols, Gaz et Précipitations en Tunisie) that a sun photometer (CIMEL CE318) was installed temporarily in Thala $\left(35.55^{\circ} \mathrm{N}, 8.68^{\circ} \mathrm{E}\right)$ in Tunisia by Laboratoire d'Optique Atmosphérique (LOA), Lille, France. These measurements have been done during March-November 2001 period and presented by Masmoudi et al. (2003) on spatial and temporal variabilities of aerosols optical thickness and size distribution. However, cirrus clouds were not part of their study in their paper.

In order to characterize aerosols layers and cirrus clouds over Tunisia, we have conducted a study using sun photometer during the period November 2000-March 2002.

Cirrus clouds and aerosols sudy

H. Chtioui et al.

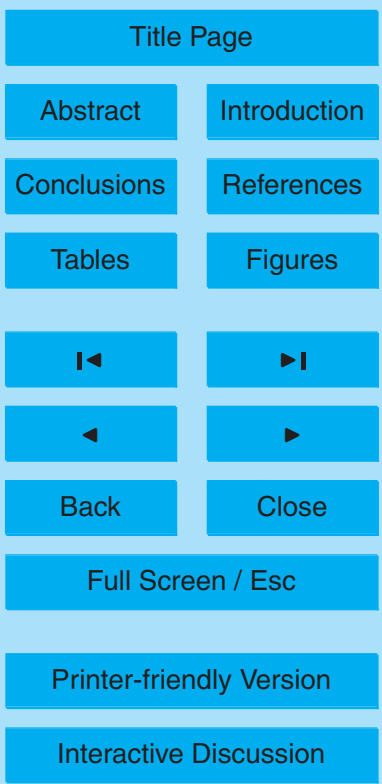


The measurements were conducted in five key sites (Fig. 1): Tunis $\left(36.50^{\circ} \mathrm{N}, 10.13^{\circ} \mathrm{E}\right)$, Sousse $\left(35.50^{\circ} \mathrm{N} 10.38^{\circ} \mathrm{E}\right)$, Gabes $\left(33.52^{\circ} \mathrm{N} 10.06^{\circ} \mathrm{E}\right)$, Gafsa $\left(34.28^{\circ} \mathrm{N}, 8.43^{\circ} \mathrm{E}\right)$ and Tozeur $\left(33.50^{\circ} \mathrm{N}, 8.07^{\circ} \mathrm{E}\right)$. Tunis, Souse and Gabes are located on the Mediterranean coast, when Gafsa and Tozeur are located in the South West part of the country, at the 5 boarder of the Sahara.

A summary of the field campaign is presented in Table 1.

\section{Instrumentation}

The sun photometer which is used in this work is a hand apparatus. It was designed in 1982 by LMD (Laboratoire de météorologie dynamique, Ecole Polytechnique, France) and LOA (Laboratoire d'optique atmosphérique, Lille, France).

The detector is a silicium photo-voltaique cell with a $200-1113 \mathrm{~nm}$ wave band. Sun aiming is mannually accomplished. So it is hard to ensure measurements every day and every 15 or $30 \mathrm{~min}$. The sun photometer is equiped with five filters in the solar spectrum: $F_{1}(532 \mathrm{~nm}), F_{2}(647 \mathrm{~nm}), F_{3}(850 \mathrm{~nm}) F_{4}(940 \mathrm{~nm})$ and $F_{5}(937 \mathrm{~nm})$. However in this work, just the filter $\mathrm{F} 1$ is used for Atmospheric optical thickness determination.

\section{Data processing}

Instrument calibration and data processing methods are the same as presented by Masmoudi et al. (2003). Here below a short description is presented. Measurements are just used to derive Atmospheric (Aerosol and Cirrus) Optical Thickness at $20 \lambda=532 \mathrm{~nm}$ where Solar attenuation is due to Rayleigh and Mie scattering (No atmospheric absorption at this wavelength).

The total extinction of solar radiation is:

$U_{\lambda}=\left(U_{0 \lambda} / S\right) \exp \left(-\tau_{t} m\right)$

Cirrus clouds and aerosols sudy

H. Chtioui et al.

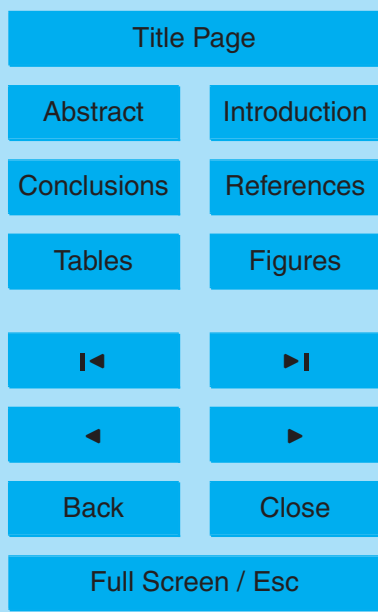

Printer-friendly Version

Interactive Discussion 
where $\tau_{t}$ is the total atmospheric thickness and $U_{\lambda}$ is the measured signal (in volts) at wavelength $\lambda$ and $m$ is the optical air mass. $U_{0 \lambda}$ is a calibration constant. In practice it is determined from a Langley plot. Clear sky conditions are used for such a calibration.

$S=\left(d / d_{0}\right)^{2}$ is the normalized earth-sun distance. $d$ is the earth-sun distance on the 5 measurement day and $d_{0}$ is the mean earth-sun distance (Paltridge and Platt, 1976)

$$
\begin{aligned}
1 / S=\left(d_{0} / d\right)^{2} & =1.000110+0.034221 \cos (a)+0.001280 \sin (a) \\
& +0.000719 \cos (2 a)+0.000077 \sin (2 a)
\end{aligned}
$$

where $a=2 \pi n_{j} / n_{t}, n_{j}$ is the day number in the year and $n_{t}$ the total number of days per year.

$10 \log \left(U_{\lambda}\right)=\log \left(U_{0 \lambda} / S\right)-\tau_{t} m$

$\tau_{t}$ is determined using a mean square fitting of $\log \left(U_{\lambda}\right)$ against $m$ plot.

$\tau_{t}=\tau_{a}+P / P_{0} \tau_{n}$

$P$ and $P_{0}$ are pressure at measurement station level and at sea level respectively.

$\tau_{n}$ is the Rayleigh optical thickness which is computed for a standard atmosphere 15 (Paltridge and Platt, 1976).

$\tau_{a}$ is the Atmospheric Optical thickness (AOT) due to particles extinction. The retrieved AOT are computed with an error of \pm 0.02 (Chiapello et al., 1999).

\section{Data analysis}

About 2000 photometric measurements were obtained during the period November

2000-February 2002 at Tunis $(d=6, n=85)$ Sousse $(d=114, n=1438)$, Gabes $(d=3$, $n=52)$, Gafsa $(d=11, n=162)$ and Tozeur $(d=15, n=263)$, where $d$ is the number of measurement days and $n$ the total number of measurements during $d$ days. Time interval between two measurements is about $20-30 \mathrm{~min}$.

6, 3321-3335, 2006

\section{Cirrus clouds and} aerosols sudy

H. Chtioui et al.

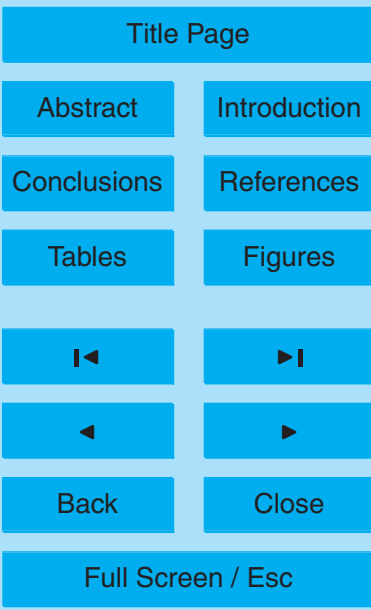

Printer-friendly Version

Interactive Discussion 
As shown in Table 2, most of the measurements have been conducted at Sousse which is our home station. The other sites were visited during a few days but at different times of the year. Table 2 contains average AOT versus month.

The maximum AOT $(=0.6)$ is measured during the March-April-May period. It is 5 well known in South Tunisia that saharan dust events occur more frequently at this time (Israelevich et al., 2003). Minimum AOT values (0.15) were measured during December-January.

It is important to mention that cirrus clouds are identified by eyes by the experimenter during measurements. As shown in Table 2, cirrus clouds are frequently observed at all sites especially during the saharan dust events over Tunisia.

At Sousse, a total of 114 days are classified as 88 as cirrus days, 14 as clear sky days and 12 aerosols days. At Gafsa and Tozeur, which are about $200 \mathrm{~km}$ away from the mediterranean coast, the AOT values $(0.14-0.24)$ are lower than those measured at Sousse and Tunis. Sousse and Tunis are located on the Mediterranean coast.

In order to check that cirrus clouds amount is enhanced by the Saharan dust transport over Sousse, wind direction at $200 \mathrm{hPa}$ is examined by using The European Meteorological Bulletin. During the field campaign (149 days), It was found that frequent wind directions were West (50 days), North-West (36 days) and South-west (20 days) directions. In other words, Instances of wind coming from the Sahara and North Algerian land (106 days) were higher than instances of wind coming from Europe and the Mediterranean areas (22 days). Most Tunisian aerosols could be Saharan. The presence of Mediterranean moisture and Saharan aerosols seems to be responsible for cirrus clouds formation (Schumann, 2002; Sassen et al., 2003). Total values of AOT versus month for the different sites are presented in Fig. 2. At Sousse, most AOT values range from 0.2 to 0.4 . Highest values were measured at Tunis. They may be due to antropogenic aerosols and also contrails due to nearly international airport.

Two stack histograms are presented in Fig. 3. Because Gafsa and Tozeur are far from The mediterranean coast, more frequently the AOT values do not exceed 0.14. However near the mediterranean (Tunis, Sousse, Gabes), most values range from 0.1

Cirrus clouds and aerosols sudy

H. Chtioui et al.

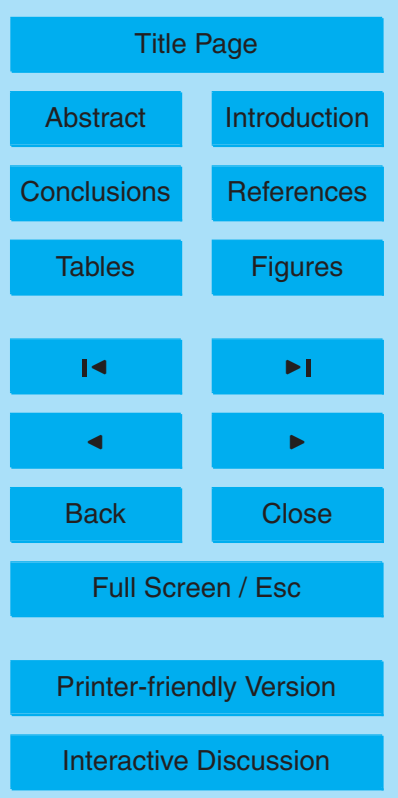

EGU 
to 0.4 . Here, AOT values lower than 0.1 are identified as aerosols cases.

In order to understand the interaction between the mediterranean and saharan aerosols, available Satellite images showing saharan dust events over the mediterranean during November 2000-February 2002, were downloaded from http://www.

5 osei.noaa.gov/Events/Dust/ and in http://www.saa.noaa.gov websites. During our field campain, no significant dust events were observed by satellite over Tunisia. Most interesting events occurred over the Libyan coast. However, a few satellite images were selected: they clearly show contrails over the saharan dust layer (Fig. 4).

\section{Conclusions and perspectives}

10 In order to characterize north african aerosols and cirrus clouds events, sun photometric measurements have been conducted at five Tunisian sites. Three of them are located on the Mediterranean coast and the others are near the saharan boarder.

Three concluding remarks may be derived from this experiment:

- In all regional sites and at most of the time, Cirrus clouds have been more frequently observed than Saharan dust.

- Also at all sites, higher AOT values (0.4-0.6) were obtained during the saharan dust period (March-May). Lower values $(0.15-0.25)$ were, however obtained during summer and winter.

- According to satellite observations, saharan aerosols can enhance contrails formation especially in Europe where air traffic is denser than over North Africa.

Perspectives

- Using satellite images, contrails formation over Europe could be studied during Saharan dust transport.

Cirrus clouds and aerosols sudy

H. Chtioui et al.

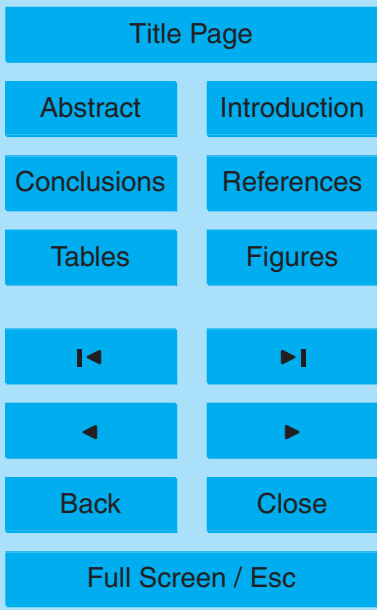

Printer-friendly Version

Interactive Discussion 
- It would be very usefull to make lidar measurements with sun photometer measurements, because lidar can distinguish between Cirrus clouds and Aerosols layers and determine their height, optical and geometrical thickness.

Acknowledgements. Thanks are due to National Oceanic and Atmospheric Administration,

5 "Satellite Active Archive" (NOAA-SAA) team for their free satellite images which are available at http://www.saa.noaa.gov web site.

\section{References}

Chepfer, H., Goloub, P., Riedi, J., Dehaan, J. F., Hovenier, J. W., and Flamant, P.: Ice crystal shapes in cirrus clouds derived from POLDER/ADEOS-1, J. Geophys. Res., 106(D8), 79557966, 2001.

Chepfer, H., Pelon, J., Brogniez, G., Flamant, C., Trouillet, V., and Flamant, P.: Impact of cirrus cloud Ice crystal shape and size on multiple scattering effect, Geophys. Res. Lett., 26(14), 2203-2206, 1999.

Chiapello, I., Bergametti, J., Chatenet, B., et al.: Contribution of the different aerosol species to 15 the aerosol mass load and optical depth over the north eastern tropical Atlantic, J. Geophys. Res., 104, 4025-4035, 1999.

D'Almeida, G. A.: On the variability of desert Aerosol Radiative characteristics, J. Geophys. Res., 92(D3), 3017-3026, 1987.

Dayan, U., Heffter, J., Miller, J., and Gutman, G.: Dust Intrusion Events into the mediterranean basin, J. Appl. Meteo., 30, 8, 1185-1199, 1991.

Demott, P. J., Sassen, K., Poellet, M. R., Baumgardner, D., Rogers, D. C., Brooks, S., Prenni, A. J., and Kreidenweis, S. M.: Africain dust aerosols as atmospheric ice nuclei, Geophys. Res. Lett., 30, doi:10.1029/2003GL017410, 2003.

Deuze, J. L., Devaux, C., Herman, M., Santer, R., and Tanré, D.: Saharan aerosols over the south of France: Characterization Derived from satellite data and Ground based Measurements, J. Appl. Meteor., 27, 5, 680-686, 1988.

Dulac, F., Tanré, D., Bergametti, G., Buat-Ménard, P., Debois, M., and Stutton, D.: Assessment of the Africain Airborne dust mass over the western Mediterranean sea using Meteosat Data, J. Geophys. Res., 97(D2), 2489-2506, 1992.

Cirrus clouds and aerosols sudy

H. Chtioui et al.

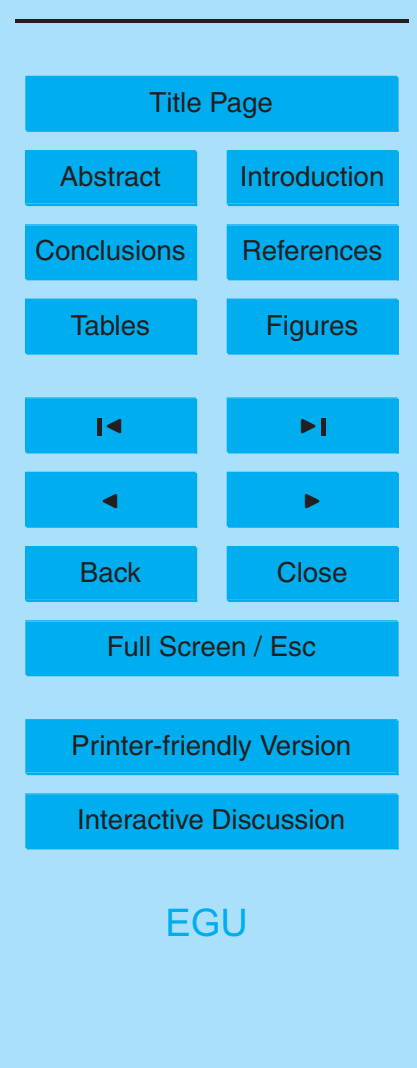


Dulac, F. and Chazette, P.: Case study of a multi-layer aerosol structure in the eastern mediterranean observed with the airborne polarized lidar ALEX during a STAAARTE campain, Atmos. Chem. Phys. Discuss., 3, 2393-2426, 2003.

Holben, B. N., Eck, T. F., Slutsker, I., et al.: AERONET - A federated instrument network and data archive for aerosol characterization, Remote Sens. Environ., 66, 1-16, 1998.

Israelevich, P. L., Ganor, E., Levin, Z., and Joseph, J. H.: Annual variations of physical properties of desert dust over Israel, J. Geophys. Res., 108(D13), 4381, doi:10.1029/2002JD003163, 2003.

Israelevich, P. L., Levin, Z., Joseph, J. H., and Ganor, E.: Desert aerosol transport in the mediterranean region as inferred from the TOMS aerosol index, J. Geophys. Res., 107(D21), 4572, doi:10.1029/2001JD002011, 2002.

Liou, K. N.: Influence of cirrus clouds on weather and climate processes: A global perspective, Mon. Weather Rev., 114, 1167-1197, 1986.

Masmoudi, M., Chaabane, M., Tanré, D., Gouloub, P., Blarel, L., and Elleuch, F.: Spatial and 15 temporal variability of aerosol: size distribution and optical properties, Atmos. Res., 66, 1-19, 2003.

Müller, D., Mattis, I., Wandinger, U., Ansmann, A., Althausen, D., Dubovik, O., Eckhardt, S., and Stohl, A.: Saharan dust over a central European EARLINET-AERONET Site: Combined observations with raman lidar and Sun photometer, J. Geophys. Res., 108(D12), 4345, 20 doi:10.1029/2002JD002918, 2003.

Paltridge, G. W. and Platt, C. M. R.: Radiative processes in Meteorology and climatology, Elsevier Scientic publishing company, New Nork, 311 pp., 1976.

Sassen, K., Demott, P. J., Prospero, J. M., and Poellet, M. R.: Saharan Dust storms and indirect aerosol effects on clouds: CRYSTAL-FACE Results, Geophys. Res. Lett., 30, doi:10.1029/2003GL017371, 2003.

Tanré, D., Devaux, C., Herman, M., and Santer, R.: Radiative properties of desert aerosols by optical Ground-Based measurements at solar wavelengths, J. Geophys. Res., 93(D11), 14223-14231, 1988.

Schumann, U.: Contrail cirrus, in: Cirrus, edited by: Lynch, D. K., Sassen, K., Starr, D. O'C., and Stephens, G., Oxford University Press, pp. 231-255, 2002.

Cirrus clouds and aerosols sudy

H. Chtioui et al.

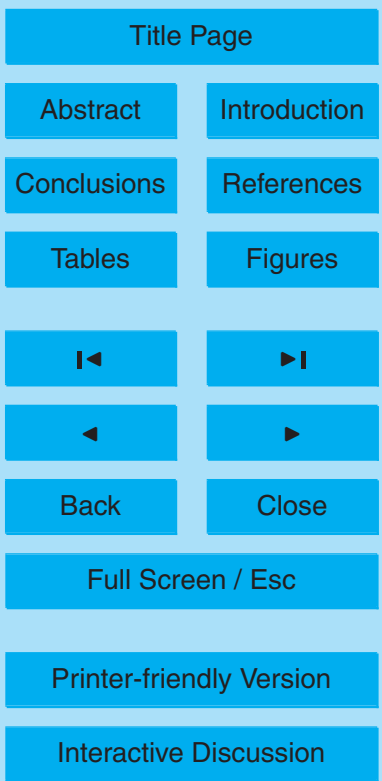


Table 1. Experiment field campaign chronology, $d$ is the number of measurements days per period. Total days: 149, with 6 days in Tunis, 3 in Gabes, 11 in Gafsa, 15 in Tozeur and 114 in Sousse.

\begin{tabular}{crc}
\hline Site & Period & $d$ \\
\hline Tunis & May 2001 & 6 \\
Sousse & November 2001-March 2001 & 62 \\
& March 2001-April 2001 & 6 \\
& May 2001 & 2 \\
& August 2001-October 2001 & 20 \\
& October 2001-November 2001 & 4 \\
& November 2001-December 2001 & 14 \\
Gabes & January 2002-Fabruary 2002 & 6 \\
Gafsa & November2001 & 3 \\
& April 2001 & 7 \\
Tozeur & November 2001 & 4 \\
& March 2001 & 8 \\
& December 2001 & 7 \\
\hline
\end{tabular}

\section{ACPD}

$6,3321-3335,2006$

\section{Cirrus clouds and} aerosols sudy

H. Chtioui et al.

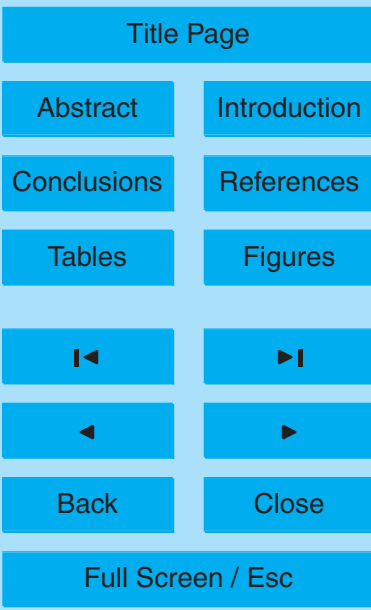

Printer-friendly Version

Interactive Discussion 
Table 2. Atmospheric Optical Thickness (AOT) and Standard deviation (Std) of Cirrus Clouds (Ci), Saharan Aerosols (Ae) and Clear Sky (CS) cases observed at each regional site. $d$ is the number of measurement days per month from November 2000 to February 2002. 76.5\% of cases are Cirrus clouds, 9.5\% Aerosols and 14\% Clear sky. Std varies from mean AOT to half.

\begin{tabular}{clcccccc}
\hline Site & Date & $d$ & CS & $\mathrm{Ae}$ & $\mathrm{Ci}$ & Mean AOT & Std \\
\hline Gabes & October 2001 & 3 & 2 & 0 & 1 & 0.24 & 0.20 \\
\hline Gafsa & April 2001 & 7 & 0 & 1 & 3 & 0.28 & 0.27 \\
& November 2001 & 4 & 1 & 1 & 5 & 0.20 & 0.10 \\
\hline Tozeur & March 2001 & 8 & 1 & 0 & 7 & 0.20 & 0.15 \\
& December 2001 & 7 & 2 & 0 & 5 & 0.14 & 0.13 \\
\hline Tunis & May 2001 & 6 & 1 & 0 & 5 & 0.40 & 0.23 \\
\hline Sousse & November 2000 & 7 & 1 & 0 & 6 & 0.60 & 0.17 \\
& December 2000 & 11 & 1 & 6 & 4 & 0.15 & 0.08 \\
& January 2001 & 15 & 0 & 4 & 11 & 0.22 & 0.21 \\
& February 2001 & 19 & 0 & 2 & 17 & 0.31 & 0.22 \\
& March 2001 & 7 & 2 & 0 & 5 & 0.42 & 0.26 \\
& April 2001 & 3 & 0 & 0 & 3 & 0.31 & 0.13 \\
& May 2001 & 2 & 0 & 0 & 2 & 0.49 & 0.09 \\
& August 2001 & 4 & 2 & 0 & 2 & 0.20 & 0.11 \\
& September 2001 & 8 & 0 & 0 & 8 & 0.27 & 0.19 \\
& October 2001 & 13 & 3 & 0 & 10 & 0.16 & 0.11 \\
& November 2001 & 13 & 2 & 0 & 11 & 0.25 & 0.16 \\
& December 2001 & 6 & 2 & 0 & 4 & 0.13 & 0.09 \\
& January 2002 & 2 & 0 & 0 & 2 & 0.32 & 0.11 \\
& February 2002 & 4 & 1 & 0 & 3 & 0.38 & 0.16 \\
\hline & Total days & 149 & 21 & 14 & 114 & & \\
& & $100 \%$ & $14 \%$ & $9.5 \%$ & $76.5 \%$ & & \\
\hline
\end{tabular}

ACPD

6, 3321-3335, 2006

\section{Cirrus clouds and} aerosols sudy

H. Chtioui et al.

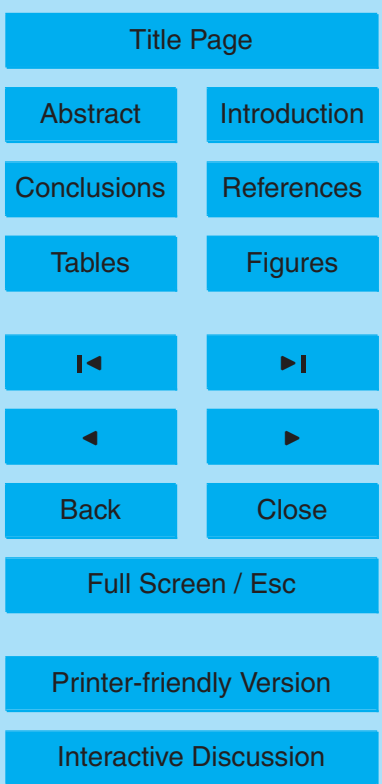




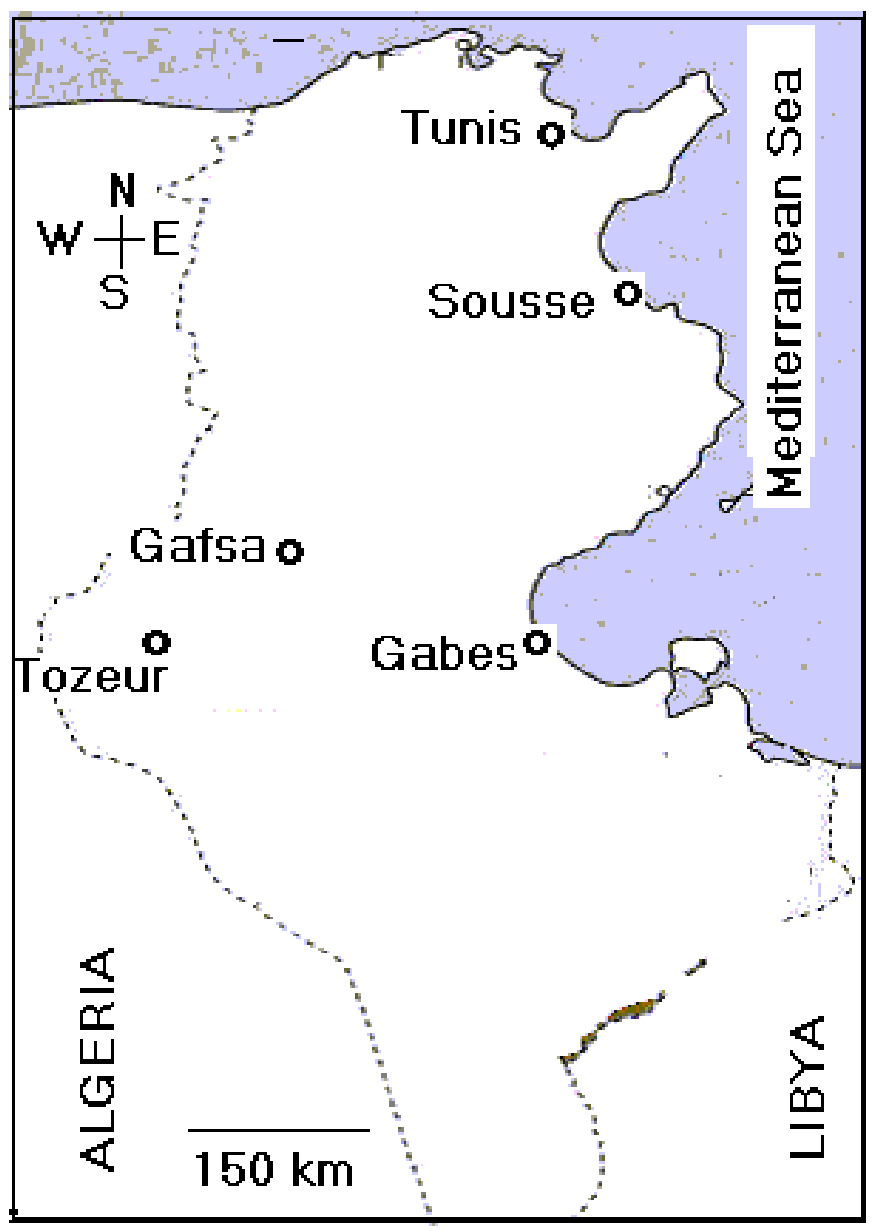

ACPD

6, 3321-3335, 2006

Cirrus clouds and aerosols sudy

H. Chtioui et al.

Title Page

Abstract

Introduction

Conclusions

References

Tables

Figures

14

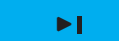

Back

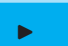

Full Screen / Esc

Printer-friendly Version

Interactive Discussion

Fig. 1. Tunisian map showing the five sites of measurements. 


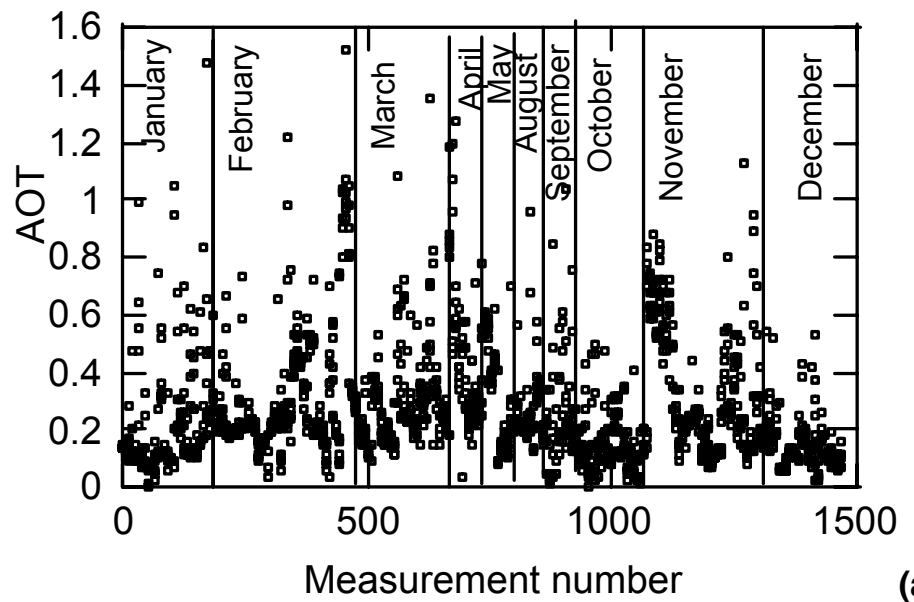

\section{ACPD}

6, 3321-3335, 2006

\section{Cirrus clouds and} aerosols sudy

\section{H. Chtioui et al.}

(a)
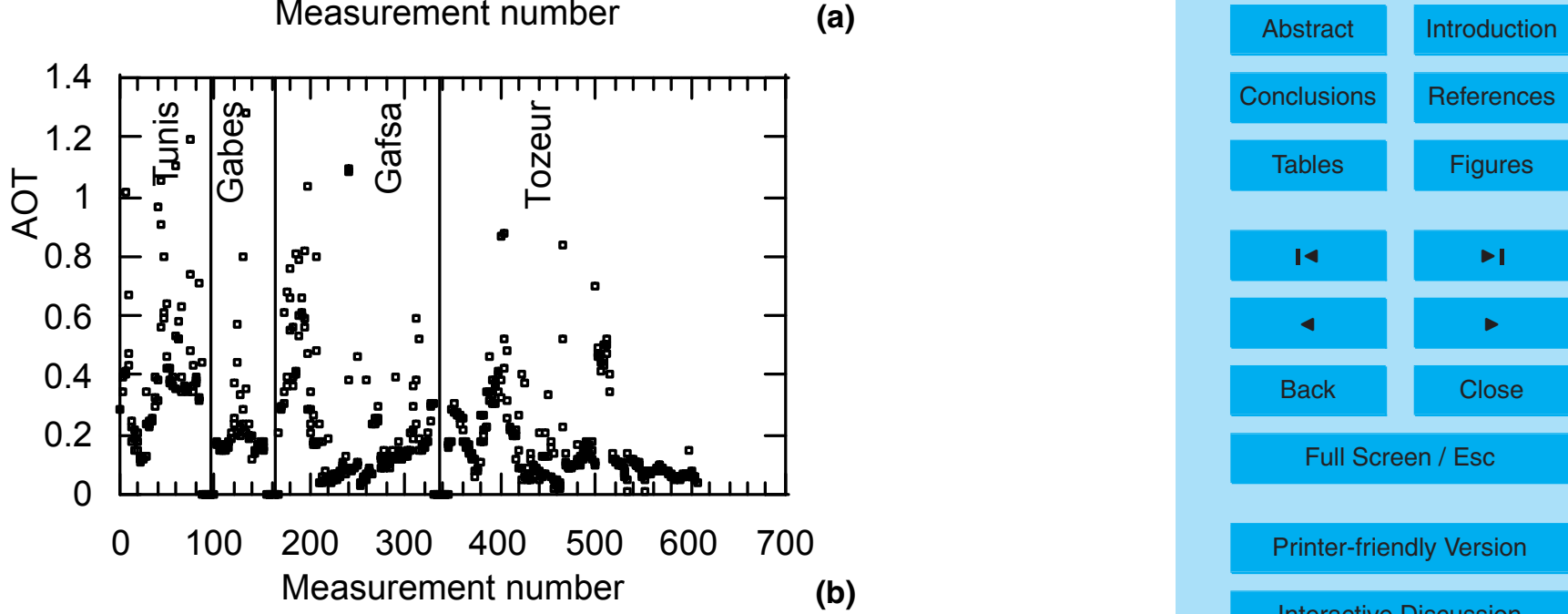

Printer-friendly Version

Interactive Discussion

Fig. 2. Total Atmospheric Optical Thichness (AOT) measured during the field campaign (November 2000-February 2002). (a) measurements at Sousse as a function of month of the year, (b) measurements at Tunis, Gabes, Gafsa and Tozeur. 


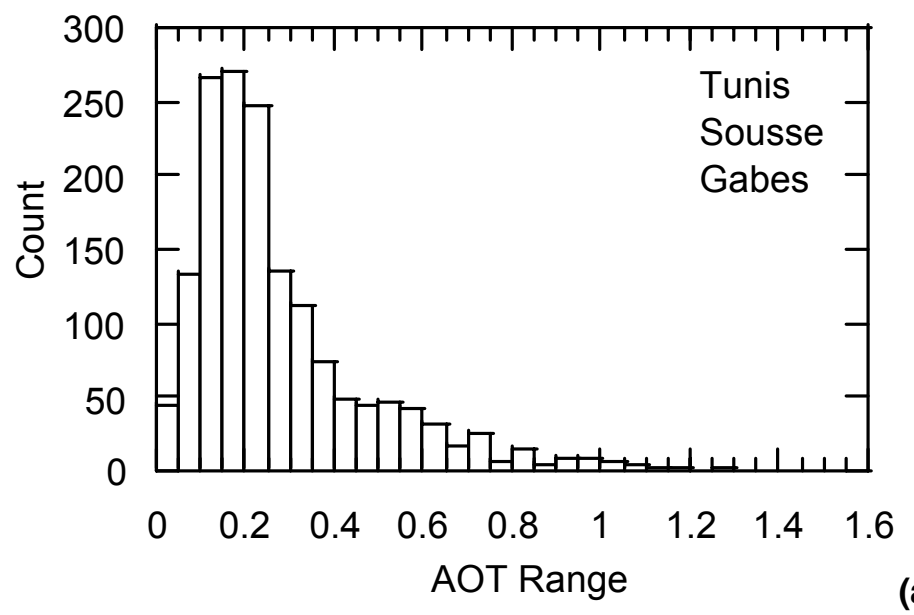

\section{ACPD}

\section{6, 3321-3335, 2006}

\section{Cirrus clouds and} aerosols sudy

\section{H. Chtioui et al.}

Title Page

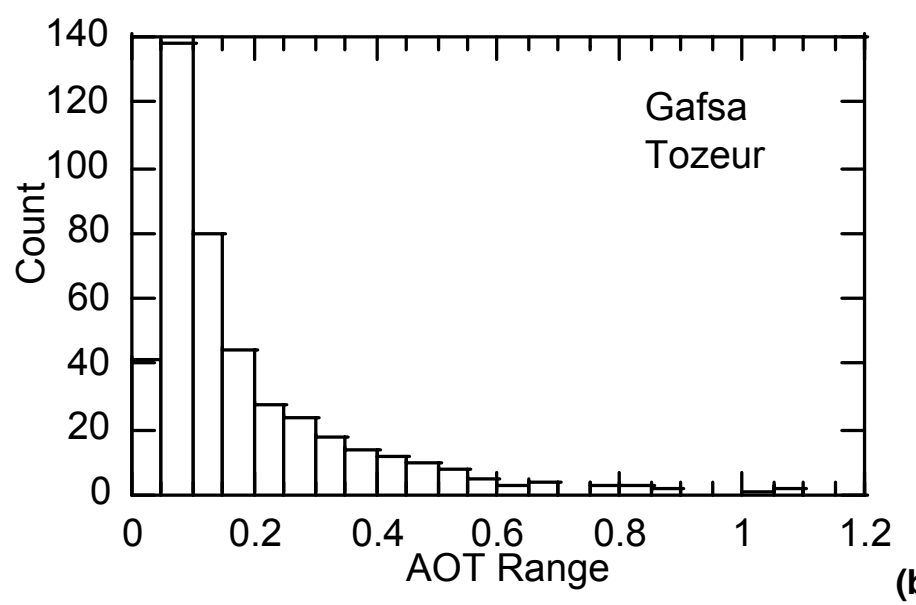

\section{(a)}

\section{Abstract}

Conclusions

Tables

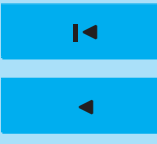

Back
Introduction

References

Figures
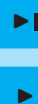

Full Screen / Esc

Printer-friendly Version

Interactive Discussion

Fig. 3. Atmospheric Optical Thickness (AOT) histograms for sites (a) near the meaditerranean coast and (b) near the Sahara boarder. 


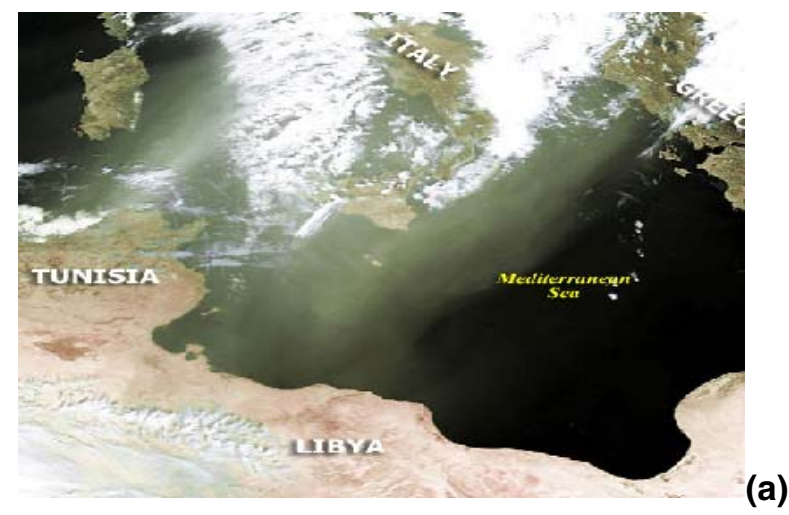

\section{ACPD}

6, 3321-3335, 2006

Cirrus clouds and aerosols sudy

H. Chtioui et al.

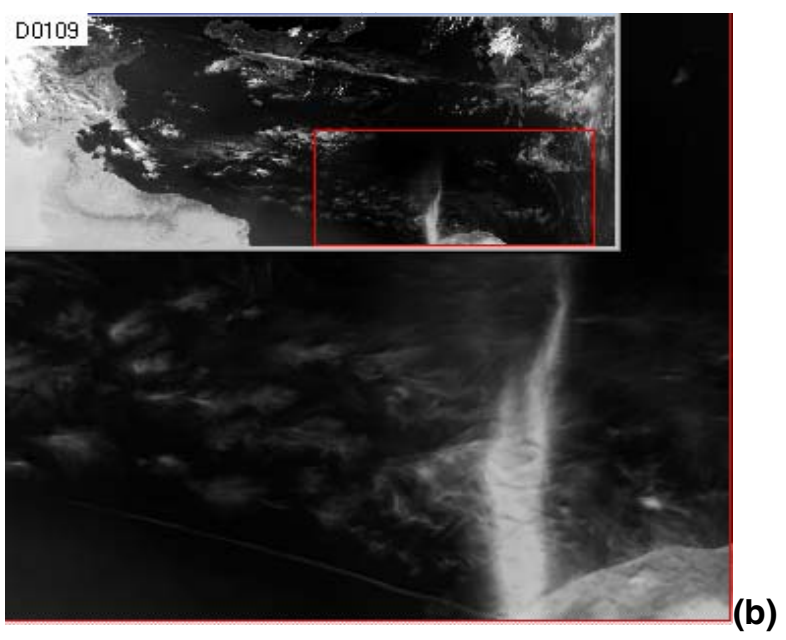

Title Page

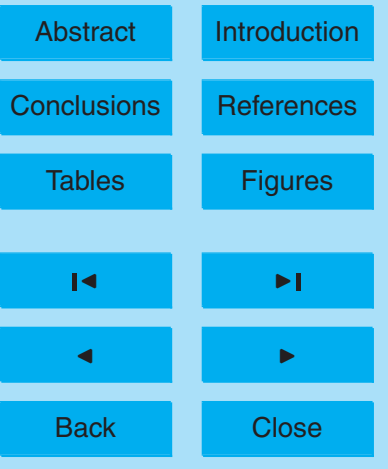

Full Screen / Esc

Printer-friendly Version

Fig. 4. NOAA AVHRR Satellite images showing Saharan dust storms and contrails over the Mediterranean Sea. (a) NOAA 16 image of 3 March 2002 at 11:45 UTC over Tunisia (imInteractive Discussion coming from Libyan area on 19 April 2001. Zoomed image shows a thin contrail near the dust plume. Reference image: NSS.LHRR.NL.DO1109.S1229.E1241.B0296363.GC downloaded from ftp://ftp.class.noaa.gov. 